\title{
Conhecer no/pelo sofrer: a vítima como sujeito no testemunho e na transgressão ${ }^{1}$
}

\author{
Allan da Silva Coelho ${ }^{2}$
}

\section{Resumo}

O sofrimento social, evento crítico que afeta o cotidiano de um grupo social, provoca uma inflexão no modo como a vítima conhece a realidade. Veena Das denomina "conhecimento envenenado" a permanência da violência na subjetividade que modifica o imaginário e os horizontes de compreensão da vida. Articulando a dimensão social e individual do processo formativo humano, provoca a Filosofia da Educação a refletir sobre as relações entre apostas éticas e a sujeiticidade da vítima. No encontro de teorias pós-colonial e descolonial, propõe-se uma revisão das categorias de Das em diálogo com o pensamento crítico latino-americano. Permanece o desafio de melhor caracterizar o conhecimento produzido na dor e na compaixão, como forma de renovação do marco categorial da Filosofia da Educação.

Palavras-chave: Perspectiva Descolonial; Sofrimento Social; Vítima; Escola do DEI; Horizontes de Compreensão.

\section{La connaissance par le souffrir : la victime comme sujet dans le témoignage et la transgression}

\section{Résumé}

La souffrance sociale, événement critique qui affecte la vie quotidienne d'un groupe social, provoque un tournant dans la manière dont la victime connaît la réalité. Veena Das intitule « connaissance empoisonné " la permanence de la violence dans la subjectivité qui modifie l'imaginaire et les horizons de la compréhension de la vie. Articuler la dimension sociale et individuelle du processus de formation humaine, amène à réfléchir sur la relation entre les paris éthiques et l'action de la victime de devenir sujet. À la rencontre des théories postcoloniales et décoloniales, une revue des catégories de Das est proposée, en dialogue avec la pensée critique latino-américaine. Le défi reste de mieux caractériser les connaissances produites dans la douleur et la compassion, permettant de renouveler la philosophie de l'éducation.

Mots-Clés: Perspective Décoloniale; Souffrance Sociale; Victime; École DEl; Horizons de Compréhension.

\section{Introdução}

A crise provocada pela pandemia mundial do novo coronavírus proporcionou uma ruptura na vida cotidiana que possui um caráter inédito para essa geração, ao menos no Brasil. A necessidade do confinamento massivo da população mundial, algo inconcebível como possível a pouco tempo atrás, permite pensar que esse acontecimento não causará impacto somente à economia, mas à diversas outras dimensões da vida humana. Mesmo frente aos limites da longa quarentena e às reflexões sobre a (im)possibilidade de redução na velocidade da engrenagem

\footnotetext{
${ }^{1}$ O presente trabalho foi realizado com apoio da Coordenação de Aperfeiçoamento de Pessoal de Nível Superior Brasil (CAPES) - Código de Financiamento 001. This study was financed in part by the Coordenação de Aperfeiçoamento de Pessoal de Nível Superior - Brasil (CAPES) - Finance Code 001

2 PPGE da Universidade São Francisco, Itatiba- SP, allan.filos@gmail.com
} 
produtiva do sistema econômico, o fato é que fomos confrontados com um acontecimento do tipo de um evento crítico. Esse tipo de reflexão, sobre como eventos críticos que produzem experiências de sofrimento social modificam a maneira de ser dos grupos atingidos, em especial, no âmbito do imaginário, das metanarrativas e de seus horizontes de compreensão da vida, tem sido a chave de leitura da obra da antropóloga indiana Veena Das.

Esse cenário global cumpre a tarefa de pretexto para os argumentos que queremos apresentar, uma vez que a atualidade e a grande escala proporcional dos afetados não modifica a estrutura organizativa do quadro categorial proposto por Veena Das. Isto é, gostaria de afirmar que, se a conjuntura atual explicita a relevância de pensarmos a relação entre o sofrimento social e o conhecimento produzido, esse cenário de pandemia apenas ressalta uma exigência que já parecia urgente ${ }^{3}$. Nossa linha diretiva, mais do que questionar se é possível encontrar relações entre o sofrimento e o conhecimento, é refletir de que maneira o sofrimento social modifica as formas de pensar, de compreender e de projetar o modo humano de ser, na perspectiva que Das chamou de conhecimento envenenado. É pensar como a construção social e subjetiva do sujeito e do conhecimento devem ser considerados pela Filosofia da Educação.

Veena Das é uma intelectual indiana contemporânea, professora em Johns Hopkins University (EUA), e trabalha com a antropologia na perspectiva pós-colonial, associando a compreensão da modernidade e do capitalismo sempre a partir do ponto de vista dos subalternos. O conhecimento é sempre perspectivado, explicitando ou ocultando suas cumplicidades. Os estudos das teorias pós-coloniais permitem um profícuo debate que colabora na renovação teórica das ciências humanas. Descortina-se que certas perspectivas acadêmicas gestam uma ciência social, positiva, cientificista, com presunção de neutralidade ideológica, que se torna alheia à dor do outro, ao sofrimento da vítima.

No Brasil, os trabalhos no campo da Filosofia da Educação que mais se interessam pelos debates pós-coloniais os abordam quase sempre em diálogo com o emergente pensamento descolonial, inseridos no circuito de autores e autoras da Filosofia latino-americana. Entre esses,

\footnotetext{
${ }^{3}$ Veena Das propõe pensar se o chamado "novo normal" não revela o velho normal, que associa a cotidiana ineficácia dos sistemas de saúde no atendimento aos pobres, a desconfiança frente tratamentos e a necessidade de conviver com mais uma forma de morrer (DAS, 2020).
}

Periódico Horizontes - USF - Itatiba, SP - Brasil - e020055 
nossa ancoragem teórica e metodológica tem como referência a chamada Escola do $\mathrm{DEI}^{4}$ ou Escola de San José, ao qual incluímos, por exemplo, Enrique Dussel e Franz Hinkelammert. Nesta Escola, a vítima é uma realidade empírica. A vítima é alguém a quem um ato de opressão, seja a exploração, a dominação ou a exclusão, inflige um sofrer que nega a sua dignidade de sujeito. Na busca pelas possibilidades de viver, a vítima emerge como novo sujeito (DUSSEL, 2000).

A partir deste ponto de convergência, propomos uma leitura da teoria de Veena Das que, com forte aspecto de interdisciplinaridade, é forjada nos marcos da antropologia. Essa leitura dialogada para além da simples descrição do quadro teórico indica uma proposta de apropriação das categorias ${ }^{5}$ que se esforça por manter coerência com a obra da autora, mas visa ampliar e aprofundar os instrumentais de crítica da Filosofia da Educação.

Como chave de leitura está a ideia central de que o conhecimento situado ou perspectivado se fundamenta nas relações de cumplicidades que desempenha na vida real. Veena Das destaca a relação concreta entre as instituições sociais e o sofrimento real dos seres humanos vitimados pela violência (DAS; POOLE, 2008). Procura verificar como se estabelecem as relações sociais nos eventos críticos de vitimação e qual o papel desempenhado pelos diversos atores sociais na disputa da significação da violência (incluindo agressores, vítimas e as teorias sociais). Apresenta-se quem experiencia a dor como sujeito capaz de conhecer as relações de subordinação e contestá-las, a seu modo, nas mais diversas realidades de degradação, pela afirmação de sua presença como ser humano, interpelante de reconhecimento e dignidade. Lauri Wirth destaca que

os estudos de Das, por seu turno, nos levam a refletir sobre possíveis consequências da destruição das convenções coletivas que dão sentido à vida cotidiana e que permeiam as relações comunitárias. Realidades marcadas pelo conflito e por tensões sociais podem abrir espaço para um fenômeno que a autora chama de conhecimento envenenado (WIRTH, 2016, p.286).

\footnotetext{
4 "Escola do DEI" refere-se ao setor do cristianismo de libertação que desenvolve um pensamento crítico articulando as ciências sociais, marxismo e a teologia para pensar a libertação das vítimas. DEl remete ao Departamento Ecumênico de Investigações que gestado no Chile, na confluência entre exilados e militantes na experiência dos governos Frei e Allende, bem como na dura repressão militar e política na implantação do neoliberalismo de Pinochet. "O DEl instalou-se em San José, na Costa Rica, nos anos 1970 e a expressão remete mais ao grupo que se articula para uma perspectiva metodológica, do que ao instituto estabelecido no bairro costarriquenho de Sabanilla" (COELHO, 2018, p.37). Veja mais em COELHO, $2014 ; 2020$.

${ }^{5}$ Nesse sentido, recorda o conceito de influência de um autor na teoria de Lucien Goldmann (apud LÖWY; NAÏR, 2008).
} 
Ao procurar as maneiras como a dor do sofrer socialmente constituído e sua relação com o conhecimento fora do marco tradicional da razão instrumental, isso é, como o sofrimento modifica o conhecimento, procuramos vislumbrar de que modo uma concepção alternativa de epistemologia pode estar a serviço da vítima ao explicitar os marcos categoriais da legitimação da violência irracional imposta como plausível.

Essa pesquisa tem como ponto de partida a categoria de sofrimento social. O conjunto da pesquisa resultou em três abordagens diferentes e complementares: (1) a teodiceia do sofrimento como justificadora de uma certa proposta pedagógica (COELHO, 2017), (2) as maneiras como o sofrimento social modifica o imaginário e os horizontes de compreensão da vida deslocando o pensar, o compreender e o conhecer, e, por fim (3) um ponto de crítica à metodologia das ciências humanas em seus limites modernos de compreender e interpretar a dor como categoria da vida social. Neste texto, temos a apresentação da síntese do item dois, as relações entre dor e conhecer, em um primeiro momento trabalhando as características do sofrimento social, as modificações no pensar e na compreensão do chamado conhecimento envenenado, para em seguida discutir o papel da vítima na elaboração deste tipo de conhecer. Na segunda parte, propomos o processo formativo do sujeito na articulação dos papéis de vítima, testemunha e transgressora do sentido geral proposto pelas instituições de poder, refletindo na perspectiva ética do ato de reconhecer ou des-conhecer a dignidade do sofredor. Sugerimos, na argumentação, que a Filosofia da Educação deve ser desafiada pela relação concreta com o sofrimento humano para evitar de se constituir como uma reflexão indiferente à dor do próximo.

\section{O sofrimento social como categoria de análise nas ciências sociais}

A noção de sofrimento social, que propomos como conceito central que organiza o quadro teórico de Veena Das, é apropriado pelos pesquisadores brasileiros em diferentes contextos, para explicitação da condição de populações socialmente excluídas vítimas de violência, seja esta originada no Estado ou na vida familiar, com atenção especial para sua repercussão nos lugares sociais e nos corpos das pessoas (CARVALHO, 2008). Boa parte dos estudos que utilizam o referencial de Veena Das no Brasil dialoga com a área da saúde, mesmo que o conceito de sofrimento enquanto social, na obra de Das, seja mais abrangente, por 
encontrar-se na intersubjetividade dos indivíduos, dentro do contexto social. Entretanto, como Das mobiliza categorias de diversas disciplinas das ciências humanas, seu uso instrumental interdisciplinar ressalta que, na compreensão da dor humana, não temos limites rigorosos de disciplinaridade. No contexto atual, em que a pandemia mundial do COVID-19 ressalta os aspectos sanitários da vida social, a dinâmica da academia em sua multiplicidade de contribuições e perspectivas evidencia que o impacto sobre a globalidade da vida humana, mesmo em seu caráter de sofrimento, tem uma perspectiva integral. No primeiro momento, propomos apresentar o conceito de sofrimento social, para em seguida propor a sua caracterização e, então, discutir o impacto desse tipo de sofrimento sobre a maneira de ser, de conhecer e de formação do sujeito, temas importantes para pensar a educação.

Veena Das entende o sofrimento social no conjunto da experiência humana completa, que afeta diversas dimensões da pessoa, incluindo as formas de conhecer, compreender e significar a vida. O sofrimento social é "o conjunto de problemas humanos que tem suas origens e consequências nas feridas devastadoras que as forças sociais infligem a experiência humana" (DAS, KLEINMAN, LOCK, 1997, p.IX).

Podemos dizer que é possível reconhecer na vida humana outros tipos e modalidades de sofrer. Designar um tipo de sofrimento com o complemento "social" explicita a especificidade do sofrer que o resultado de uma relação social, na qual a experiência humana, individual, é marcada profundamente por feridas devastadoras infligidas por forças sociais. Tais feridas provocam problemas humanos profundos, na subjetividade individual, bem como na intersubjetividade do grupo social.

A qualificação do sofrimento como social indica algumas de suas características fundamentais, como sofrer resultante de uma relação real entre um agente agressor e o receptor da agressão, da violência, enquanto vítima. Este agente agressor atua em nome de uma instituição de poder (política ou econômica) e/ou conta com sua cumplicidade na ação violenta. O ser humano vitimado por tal ação, sofre certa experiência de dor que provoca um ponto de inflexão, seja na vida daqueles que a sofrem diretamente, seja daqueles que são histórica ou imaginariamente alcançados por ela. Pode parecer redundante a escolha de termos para expressar a relação implícita no conceito de sofrimento social, mas tal categorial tem sua força justamente na capacidade de atentar para todos os elementos presentes em uma expressão que 
possui sutilezas preconcebidas. Destacamos além da relação real entre agente da agressão e a vítima que a sofre, a ideia de certo ponto de inflexão e seus impactos, que podem ser diretos ou indiretos, pelo alcance histórico ou imaginário.

João Eduardo Carvalho (2008) colabora em conceder concretude à ideia exemplificando algumas possibilidades que o conceito de sofrimento social pode assumir na obra teórica de Veena Das. Nele, poderíamos refletir

uma grande variedade de experiências de dor, trauma e distúrbios - na fome, na violência doméstica, no stress pós-traumático, na doença crônica, ou nas doenças sexualmente transmissíveis que envolvem, simultaneamente, situações de saúde, bem-estar, justiça, moralidade e religião. [...] Suas raízes estão, desta forma, intimamente ligadas aos processos sócio-políticos nos quais podem ser encontradas a violência e a opressão, o que não restringe esse sofrimento às populações dos países pobres do $3^{\circ}$ mundo, mas também pode ser encontrado nas 'margens' dos países ricos (CARVALHO, 2008, p.10-11)

Mesmo que a violência esteja presente de maneira ostensiva na sociedade brasileira, a categoria do sofrimento social procura englobar a violência cometida por uma instituição social ou pelo Estado, ou ainda, em nome deles ou com sua conivência, tendo como impacto não apenas um indivíduo, mas com certa repercussão no grupo social, modificando critérios de análise e de ação. Não se trata de um critério rígido, mas relacional. Um vírus mortal nessa pandemia não é, evidentemente ${ }^{7}$, uma ação de instituição nem mesmo contamina as pessoas em nome do Estado. Porém, uma pandemia que encontra políticas de saúde pública e coletiva sucateadas e com investimentos congelado constitucionalmente por mais vinte anos (Emenda Constitucional 95/PEC 241), pode ter um aspecto de dramaticidade elevado e repercussão social potencializada no já doente sistema de saúde.

Para instigar a análise, podemos refletir sobre a dimensão social do sofrimento em casos exemplares, como o rompimento das represas das mineradoras Vale e Samarco, o assassinato

\footnotetext{
${ }^{6}$ Parece-nos possível pensar que o sofrimento social não se limita aos países da periferia e, por vezes, à margem dos países ricos, mas como categoria estruturante das relações sociais modernas e capitalistas, portanto, presente em todo o seu sistema (apud COELHO; CORREIA, 2019).

7 "Evidentemente" está utilizado de maneira provocativa, referindo-se às evidências cartesianas do pensamento moderno e, ao mesmo tempo, aludindo ao processo de negação de certa racionalidade moderna em que parcela da população mundial credita a difusão do vírus a ação organizada de um país, da Organização Mundial da Saúde ou de alguma corporação global, entre outras.
}

Periódico Horizontes - USF - Itatiba, SP - Brasil - e020055 
de lideranças pela milícia, como no caso não solucionado da vereadora socialista Marielle Franco (PSOL), bem como da longa lista de assassinatos de defensores de direitos humanos, militantes sindicais, ecologistas, lideranças políticas e indígenas. Cada violência deste tipo específico tem um relativo impacto em determinados grupos sociais que poderiam modificar o processo formativo de uma maneira de ser, de conhecer a vida e de se sujeiticizar? Essa dimensão está presente como pano de fundo que instiga a organização do marco categorial que propomos, quando dialogamos com o conceito de sofrimento social de Veena Das.

Longe de propor um exercício acadêmico neutro e à frio, propomos pensar se o quadro categorial em questão permite refletir sobre a modificação no processo formativo do modo de ser humano de quem pertence a um grupo social que experimenta o atentado do crime organizado, a chacina como realidade do bairro, a repressão abusiva dos movimentos sociais como se conheceu na Copa do Mundo no Brasil - e na aplicação da lei antiterrorismo. Caberia ainda refletir se tal quadro categorial poderia incluir os impactos subjetivos mais gerais do neoliberalismo e de suas ferramentas de gerenciamento, seja a performatividade, a autoexploração extrema, mas também concretizada na retirada massiva de direitos sociais, golpes jurídico-parlamentares ou na lógica persecutória de processos judiciais de condenação prévia por acento político ideológico. Parece-nos que se as categorias de Veena Das não são propostas originalmente para este grupo de violência social, pelo tipo de metodologia e o olhar a que se propõe, mesmo assim permitem o exercício criativo de relacionar outras interpretações ao provocativo aparato teórico da antropóloga indiana.

Retornando ao conceito de sofrimento social, o aspecto social que caracteriza tal sofrimento por sua vinculação aos processos sócio-políticos, articula o sofrer do indivíduo (e de cada pessoa humana) a uma série de estruturas de significação da vida em sociedade. Este sofrimento difere-se por ser fruto de uma violência social que é incorporada ao dia a dia das pessoas. A violência social, diferente do que se sugere como algo externo, ocasional, patológico, teria sua presença no cotidiano, na relação entre as instituições e os indivíduos subalternizados, sujeitados às consequências das estruturas que geram dor e sofrimento. No entanto, o estudo de Das não considera qualquer violência social, mas conceitua e busca os chamados "eventos críticos" (critical events), isto é, os acontecimentos provocadores, caracterizados pela 
agressividade das instituições (como a família e o Estado) ${ }^{8}$, que modificam o modo de viver e de compreender a sua existência, expressando certa permanência.

Desse modo, ao invés de localizar os efeitos da violência na patologia do indivíduo, Veena Das busca captar como a dimensão subjetiva, vivencial, destes sofrimentos é modificada e modifica a realidade social do sofredor. Por isso, parte de sua pesquisa está direcionada às modificações da vítima enquanto receptor da violência, mas em especial, enquanto agente frente à violência sofrida.

$\mathrm{Na}$ interpretação de Ortega, a violência extrema do evento crítico é reconhecida como um trauma social, no qual sua vivência intensamente ameaçadora provoca efeitos coletivos. Muitos destes efeitos são apenas visíveis nas marcas que deixam nas vítimas, mas sua principal característica é a sutil modificação no imaginário da comunidade, em que o sofrimento social transforma "as redes simbólicas (em especial as associadas à lei, ao coletivo e à espiritualidade) e imaginárias (autoridade, nação, religião) que dão sustento a vida social" (ORTEGA, 2008, p.28). Nesse sentido, Veena Das destaca o papel das teodiceias ${ }^{9}$ enquanto linguagens religiosas que atuam nas redes simbólicas legitimando a violência das instituições sociais ${ }^{10}$.

O acontecimento da violência desoladora (evento crítico) em geral é um fato que se constitui temporalmente como passado, já vivido e irrepetível como tal, mas permanece presente no cotidiano, mesmo que de maneira simbólica, atuando nas formas de "prever" e "organizar" o futuro. Nem todas as violências são simbolizadas e trabalham sobre a sociedade do mesmo modo, uma vez que há diversas variáveis nas possibilidades e modos de assimilar a agressão. Por exemplo, se o sofrimento é causado por membros da comunidade ou por agentes externos à mesma, se é provocada pelo Estado ou por indivíduos associados comumente à delinquência, ao crime organizado ou à milícias... se é inesperada ou amplamente antecipada e

\footnotetext{
${ }^{8}$ Entre outros possíveis, como grupos religiosos ou filantrópicos, indústrias químicas e farmacêuticas que mantém centros de pesquisa em países pobres, ou a ausência do Estado, que permite a fragmentação da possibilidade da vida humana, como Das cita no Brasil ou na Índia (CARVALHO, 2008; DAS et ali., 2002).

${ }^{9}$ Utilizamos o conceito de teodiceia como na filosofia clássica, no contexto de uma teoria na qual se justifica o sentido do mal mesmo diante da bondade divina. Uma elaboração teórica que pretende demonstrar racionalmente que a presença do mal no mundo não entra em conflito com a bondade de Deus. Em Veena Das, o termo está associado às formas de legitimação religiosa da sociedade diante das formas de mal na violência.

${ }^{10} \mathrm{O}$ tema da teodiceia que se constrói em torno ao sofrimento social no mundo moderno e capitalista é importante e constitui, segundo a própria Veena Das, uma espécie de concepção pedagógica na qual o sofrimento tem um valor moral positivo atuando pelo engrandecimento ético e humano daquele que sofre, em um processo educativo. Como já apresentamos na introdução, aprofundamos esse tema em outro trabalho (veja COELHO, 2017).
} 
temida, se é eventual ou duradora, se atinge a toda a comunidade ou somente aos mais pobres, se vitimiza com mais força os historicamente já mais afetados como mulheres, crianças, estrangeiros ou pessoas de outras raças/etnias.

A agressão, enquanto fato vivido, desestabiliza categorias socialmente aceitas, modificando a lógica explicativa da vida hoje, fragilizando os grandes relatos sociais. O evento crítico leva a questionar o sentido geral das metanarrativas que apontam um sentido na compreensão da história e dos fatos sociais. Desse modo, modificam os horizontes de compreensão que organizam o pensar, o compreender e o conhecer com sentido. A violência extrema, mesmo silenciando as vítimas e demais afetados, permite a "previsão" do sofrimento, permanecendo sempre um rumor, um ruído das vítimas silenciosas que identificam sua marca. Veena Das diz que "se a maneira de estar com os outros foi brutalmente ferida, então o passado entra no presente não necessariamente como uma recordação traumática, mas como conhecimento envenenado" (DAS, 2008, p.244).

Ortega (2008) propõe diferenciar três níveis em que o sofrimento social modifica a vida presente. Entendemos que, mesmo se esses níveis estejam interligados e, por vezes, sejam difíceis de serem isolados, permitem pensar a abrangência dessa modificação, gerando questões importantes para entendermos o conhecimento humano, ampliando significativamente o campo de investigação da Filosofia da Educação, em especial na crítica dos marcos de plausibilidade dos horizontes de sentido da vida e das relações entre as dimensões antropológica, ética e pedagógica. O primeiro nível refere-se ao âmbito dos fatos e das mudanças concretas na vida, quando os eventos críticos questionam a viabilidade da comunidade e da vida que se vivia. A vida como era entendida é arrasada e coisas que significavam algo antes, podem perder totalmente seu sentido. Na teoria de Veena Das, o resultado não é o fim da sociedade, mas a modificação dos critérios de significação da vida coletiva.

O segundo nível é o da apropriação simbólica, no qual o evento crítico se apresenta com um caráter inacabado evidente, uma vez que a vida individual e os grandes projetos coletivos do momento atual devem legitimar-se perante o acontecimento. $O$ terceiro nível está nos impactos que moldam futuros e horizontes de perspectivas. Estes dois níveis estão no centro da disputa do sentido simbólico da violência e, em geral, gestam teodiceias explicativas de sentido. Estes temas são bastante significativos para o estudo das maneiras de ser humano enquanto 
possibilidades articuladas a projetos de sociedade, como na forma em que nos apropriamos da teoria de Paulo Freire, em que o humano como ser inacabado está aberto à diversas possibilidades de historicidade, em geral, reificados e adequados ao modo de ser do opressor (COELHO, 2018).

Retomando o raciocínio de Veena Das, se a maneira de estar com os outros foi brutalmente ferida e o conhecimento envenenado apresenta-se como o passado presente, poderíamos dizer que o veneno é a impregnação da violência na experiência da vida ${ }^{11}$. O veneno está incorporado à vida da vítima e permeia seu modo de conhecer a realidade hoje. O acontecimento sobrevive em versões diversas dentro da memória social dos diferentes grupos sociais, atuando nas compreensões da vida atual, que mantém a referência na violência sofrida. Modifica opções fundamentais, apostas e objetivos da vida, mesmo que possamos considerar que tais inflexões no modo de gestar a compreensão da vida tenham, em cada caso de diferentes maneiras, algo de imaginativo e/ou exagerado. A equivalência da inflexão provocada pelo sofrimento a uma mensuração objetiva não é o aspecto central, mas sim a reflexão sobre o modo como o conhecimento mediado pelo veneno introjetado, que se expressa abertamente ou como rumor, modifica a maneira de ser.

Pereira, contribuindo para compreender essa questão utilizando o quadro conceitual de Veena Das, afirma que o rumor

ocupa uma região da linguagem que pode fazer experimentar acontecimentos e, mais do que se apresentar como um ato externo, termina por produzir no mesmo ato em que enuncia. Os processos de tradução e rotação funcionam para atualizar certas regiões do passado e criam um sentido de continuidade entre os acontecimentos, conectando-os entre si (PEREIRA, 2016, p.362).

\footnotetext{
${ }^{11}$ Veena Das pesquisou na Índia na região de fronteira com o Paquistão, estudando por décadas os testemunhos da violência da Partição (divisão territorial efetuada entre Índia e Paquistão em 1947, pouco tempo após suas independências político-administrativas do império britânico). Esse "evento crítico" caracterizou-se pela violência entre diversos grupos étnicos e religiosos desalojando cerca de 14 milhões de pessoas e matando ao menos um milhão. Vale lembrar que a menção ao "envenenamento" acontece também no trabalho de Das quando as mulheres vitimadas e violadas sexualmente neste processo, expressavam a violência que sofreram de forma indireta, representando-a em seu corpo como um veneno introjetado e jamais expelido, sempre presente. Dizer um veneno introjetado faz sentido à posteriori, como permanência da experiência violenta e absurda, mas, no caso de certas violências como as sexuais, o estupro, por exemplo, é preciso sempre afirmar o sentido de introjetar não como uma ação sobre si mesma e explicitar a ação de outro, um homem específico, que coloca algo que envenena no corpo de outrem que não o aceita.
}

Periódico Horizontes - USF - Itatiba, SP - Brasil - e020055 
Assim, os rumores, atuando no sentido do enunciado, formariam "campo de força" (PEREIRA, 2016, p.363) que levam as pessoas a uma ação influenciada, envenenada pelo evento crítico origem do sofrimento. O rumor, numa relação que deturpa a compreensão clara entre agressores e agredidos e o senso de realidade, complexifica as categorias convencionais que temos para pensar a violência. Cria-se a expectativa permanente de que sempre é possível que algo cruel nos atinja.

Trata-se do processo formativo de uma representação da violência sofrida, em que o sujeito percebe de certo modo o acontecido, mesmo que sua percepção não corresponda necessária e objetivamente ao acontecimento. No entanto, este conhecimento envenenado não conduz inevitavelmente à passividade das vítimas como sofredores, pacientes da dor. Isto porque, a memória do passado é reconstruída a cada dia, nos gestos, nas desconexões e, mesmo, nas ousadias do silêncio.

Vale destacar que nem todas as formas de violência podem ser "racionalmente" compreendidas. Por vezes, algumas configurações da violência provocam um profundo questionamento da "humanidade" do ser humano. A ação violenta que absurdamente aparece realizada pelo humano e questiona o fundamento da humanidade daquele que a pratica, referese a qual lógica? Como compreender, significar e registrar na memória estes eventos para os quais não há palavras? (CARVALHO, 2008).

Segundo Carvalho, o conhecimento e a compreensão destes acontecimentos críticos poderão dar-se no cotidiano, em explicações que não se restringem às gramáticas convencionais. No cotidiano, encontramos a maneira como a vítima, mesmo sem palavras para explicar, encontra seu modo de relacionar-se e continuar a sua existência, com algum sentido. O cotidiano é o lugar de recuperação do sentido, no qual Das procura uma realidade encarnada, feita de pessoas, problemas, afetos, indiferenças e conflitos. Podemos dizer que o sofrimento social possui uma concretude, por supor uma dor real na corporeidade real em relação social real. A expressão "corporeidade" insere a dor em uma concepção não dualista do ser humano, pois se apresenta ao corpo e à mente de forma indivisível.

Outra característica importante na conceituação do sofrimento social é a contestação da noção de que o sofrimento conduz à elevação moral dos indivíduos. Veena Das ressalta que o sofrimento pode levar a atitudes moralmente condenáveis, como o questionamento do 
convencionalmente chamado "amor materno" em situações de profundo sofrimento pela fome. As vítimas podem, tornar-se capazes de atitudes tão violentas e consideradas "des-humanas"12.

Os sofredores não seriam passivos pacientes, são sujeitos da experiência da dor. Sujeitos da dor deste sofrimento social. Assim, são capazes, de certo modo, de representá-la interna e externamente. Seja com palavras ou no corpo, seja com gestos sutis ou rituais, elaboram estratégias que permitem subjetivar a experiência da dor. Esta apropriação acontece dentro dos parâmetros culturais, isto é, a experiência da dor acontece, se expressa e é representada dentro da cultura, que é signo de certas maneiras de ser, muitas vezes cúmplices dos atos violentos.

\section{A vítima e a resistência pelo testemunho}

Por um lado, o sofrimento possui uma conotação de passividade na medida em que quem sofre é o receptor da ação de outro (algo ou alguém). A noção de paciência ou paixão possui forte conotação de passividade. Por outro lado, no entanto, ao afirmarmos que o sofredor se torna sujeito de sua dor, estamos identificando-o não somente com a passividade, mas com a agência, seja do conhecimento, mas também sujeiticidade -no sentido freiriano (COELHO,2020), de intervenção na sociedade a partir da dialética entre realidade histórica de desumanização e a vocação ontológica a humanizar-se, ser mais, por exemplo (FREIRE, 1979). Tal compreensão parece convergente com a noção de sujeito reprimido de Hinkelammert (2002).

Constituindo-se sujeito, o sofredor acumula os papéis de vítima, testemunha e mesmo de transgressor. Estabelece uma relação direta com o agressor, numa perspectiva sua, subalterna, de experienciador da dor. Esta relação com o agressor, uma instituição, o Estado ou ambos, não é de passividade, mas de geração de novos contextos, que re-significam as relações sociais nas quais se encontram e nas quais se tornam vítimas. $O$ sentido que os sujeitos subalternos concedem à existência nem sempre corresponde ao atribuído pelas estruturas, sejam as instituições, os sistemas de ideias das ideologias vigentes ou as lógicas gerais dos grandes relatos do pensamento científico dominante.

\footnotetext{
12 Veena Das (2002) apresenta o estudo de Nancy Scheper-Hughes sobre as mulheres de Bom Jesus da Mata, no Brasil, que deixavam os bebês mais fracos morrerem por falta de cuidados mínimos e atenção. Para Das, no contexto do artigo, uma atitude de violência plenamente questionável pela convenção, mas que indica o limite da tese do sofrimento como aprimoramento moral.
}

Periódico Horizontes - USF - Itatiba, SP - Brasil - e020055 
Esta "agência", em que se sujeitiza o sofredor, rompe a lógica comum de oposições rígidas entre situações limites, como entre vítima e agressor, agência e opressão, violência e normalidade, sofrimento e paz, entre outros. A ação de resistência do sofredor, na teoria de Veena Das, supera também a "habitual associação entre agência e transgressão, como se a voz das vítimas só pudesse se manifestar transgredindo e enfrentando a Lei" (PEREIRA, 2016, p.357), demonstrando que no cotidiano, resistência e submissão podem estar próximas. A perspectiva proposta por Das indica que nem sempre a violência cruel seria esporádica, exigindo uma resistência heroica ocasional ao opressor ou à Lei.

Dessa forma, a resistência não precisa ser, necessariamente, um ato deliberado de oposição. Pode acontecer também fora deste modelo de resistência heroica ou de momentos de clara rebelião histórica dos subalternos ${ }^{13}$. Franz Hinkelammert defende, de maneira que nos permite uma aproximação coerente, que a pessoa humana reprimida em suas condições de vida, experimentando diversas formas de negação de sua dignidade, sujeitiza-se na rebelião frente a lei que oprime, uma rebelião que o torna sujeito no engajamento pela vida real. Para Hinkelammert, rebelião do sujeito é toda atitude de contestação da legitimidade da subordinação da vida e do esmagamento da dignidade humana por qualquer instituição social. Desse modo, a rebelião não se caracteriza apenas pelo enfrentamento heroico, mas pelo processo de discernir frente a violência em busca da dignidade (HINKELAMMERT, 2002). Para ambos autores, os subalternos resistem todos os dias (cotidiano) a muitas formas de violências absurdas e podem manifestar seu testemunho de resistência de diversas formas.

No entanto, do mesmo modo está claro para a antropóloga que nem toda passividade é uma resistência alternativa. Para Veena Das, existe sofrimento, associado à teodicéias legitimadoras que revelam o pior e mais terrível da capacidade ideológica das ideias religiosas, que conduz à pura possibilidade pragmática de cada um

Suportar, sobreviver e inclusive adaptar-se às condições mais desumanas. (...) Entre o potencial do sofrimento para a criação de indivíduos e comunidades morais, e seu potencial para a destruição de qualquer cosmologia dentro da qual o sofrimento poderia ter sentido, encontramos a lacuna mais criativa (DAS, 2002).

\footnotetext{
13 Sem desmerecer de nenhuma maneira as conjunturas históricas em que necessariamente os subalternos se rebelam contra as mais diversas formas de opressão e sofrimento.
} 
Neste espaço de diversidade, encontramos desde os sofredores rebeldes, que se organizam e lutam por libertação até os mais resignados, em nada rebeldes e descrentes de possibilidades de qualquer solução. No entanto, mesmo nestes, é possível que seja encontrada uma lógica diferente de resistência, muitas vezes invisível para a racionalidade e metodologias das ciências sociais ${ }^{14}$.

De acordo com Carvalho (2008), mesmo que não se possa inferir uma resistência calculada, temos a existência possível, que interfere na realidade e não significa simples submissão às linguagens vigentes. Acompanhamos essa perspectiva ${ }^{15}$, pois a ex-sistência como uma in-sistência em permanecer vivo, testemunha a realidade do sofredor enquanto experienciador da dor. A existência possível da vítima, um sofredor que insiste em existir, permite testemunho, um testemunho que pode levar ao julgamento do agressor. O rosto da vítima denuncia a existência, mesmo que velada, deste agressor.

O testemunho como um relato dos fatos, produzido pelas vítimas, nos contextos violentos dos eventos críticos, para Veena Das é fonte obrigatória de informação para as ciências sociais (e para nossa reflexão acadêmica). O testemunho é uma forma de atestar a vontade de viver de quem o enuncia, configurando-se como relato da experiência do ponto de vista subalterno. Por vezes, o testemunho não é pronunciado pela própria vítima, que se sente incapaz de fazê-lo, mas pode ser oferecido por quem sofreu de perto os efeitos indiretos e imaginários da violência. Nesse contexto, o falar é mais relevante do que quem fala, marcado por "processos subjetivos e coletivos, estruturados por tradições simbólicas e canalizados por gêneros discursivos. Uma leitura atenta do testemunho deve abrir-nos simultaneamente à cotidianidade do acontecimento e ao testemunho enquanto acontecimento" (ORTEGA, 2008, p.40).

O testemunho da vítima torna-se uma forma de responder à violência, mediada por processos subjetivos e intersubjetivos, referenciados por símbolos e gêneros discursivos da cultura em que se vive. O relato social que descreve uma experiência traumática apresenta-se

\footnotetext{
${ }^{14}$ Trabalhamos em outro texto sobre os limites e potenciais das ciências humanas em conhecer metodologicamente a dor, em direção distinta, mas complementar, do sujeito sofredor que conhece na experiência pela dor.

${ }^{15}$ Essa temática está presenta também na obra de setores da Filosofia produzida na América Latina como em Enrique Dussel, Franz Hinkelammert e mesmo, com outra estrutura conceitual, em Paulo Freire. Para aprofundar a relação, veja DUSSEL, 2000.
}

Periódico Horizontes - USF - Itatiba, SP - Brasil - e020055 
como digressão e reconstituição da experiência. Enquanto digressão, apresenta a melancolia que re-memora um fato "sem-razão", um evento de caráter arbitrário, um sofrimento ao qual não há justificativa plausível para o grupo social que o experimenta. Como reconstituição, o relato social articula o sentido coletivo de pertença, "avaliando" as perdas sofridas, reorganizando a vida às novas condições de sobrevivência, dentro das possibilidades que restaram.

Enquanto relato social das vítimas, o testemunho participa da disputa de significados, entre os sentidos perdidos ou desconstruídos. Das insiste no trabalho de reparação cotidiana pelo testemunho. Se a violência possui um caráter absurdo de perda, a busca do testemunho "evidencia o tempo e a recursividade dos seres humanos para suportar o sofrimento, para apropriar-se das perniciosas marcas da violência e re-significá-las mediante o trabalho de domesticação, ritualização e re-narração" (ORTEGA, 2008, p.43).

A partir das feridas, a domesticação, a ritualização e o re-contar permitem gestar uma continuidade para a vida no mesmo "espaço" da devastação. O testemunho que surge das feridas, do sofrimento, da dor experienciada, aconteceria em dois tipos de registro, o discursivo e o corporal (mesmo nas "zonas de silêncio").

O testemunho discursivo utiliza a linguagem para representar sua forma subalterna de compreender a experiência da dor a qual foi/está submetido no sofrimento. Este testemunho que se narra rompe o instituído e institui outra perspectiva. O "dito" é o instituído, seja nas versões dos agressores, seja nas legitimações e justificativas ideológicas ou religiosas, seja nas análises frias das ciências sociais que ignoram o significado da dor do sujeito subalternizado. $\mathrm{O}$ "dizer" já é por si só uma certa contestação, acrescenta algo às versões oficiais e aponta um relativo limite nas justificativas sacralizadas ou análises científicas.

Testemunhar o sofrimento social é expressar a experiência da dor como subjetividade, mas também como intersubjetividade. Seu dizer é apresentar sua dor. No nível imediato, a dor é um gemido, um grito, uma interpelação como reclamação que exige atenção também imediata. No testemunho da dor, mantém-se o caráter da interpelação, pois apresentar a dor sofrida constitui-se um apelo, um chamado que pode ser atendido ou ignorado. Enrique Dussel caracterizou esse apelo como base da constituição da consciência ética, no "escutar a voz do outro, palavra transontológica que irrompe de além do sistema vigente" (DUSSEL, 1995, p.65).

Atender ao apelo da dor manifesta é um reconhecimento do outro como sujeito imediato 
desta dor que o faz sofrer. Ignorar este apelo é negar ao outro a existência de sua dor. Para Dussel, é preciso ter a razão disposta, a partir da formulação de uma opção fundamental, para compreender o significado da violência que gera sofrimento. O testemunho impõe um tipo de comunicação que não aceita um simples diálogo, exige um posicionamento que supõe um compromisso ${ }^{16}$. Se temos uma negação, trata-se de uma duplicidade da violência, pois desconhecendo o sofrimento, perpetua-o. Por isso, defendemos ser o âmbito fundamental das apostas entre não conhecer ou re-conhecer o outro em seu apelo um momento importante da formação da consciência ética. Tal negação, isto é, o desconhecimento (ou opção por não a considerar relevante) é, para Veena Das, uma falta espiritual. Ortega defende que deve ser uma "falta espiritual e intelectual" (ORTEGA, 2008, p.56). Acredito que este acréscimo se dá por não compreender, como Das, a dimensão religiosa em seu modo de significar a existência, para legitimar a violência, tornando-se agente ou cúmplice, ou contestando-a, na resistência direta ou do cotidiano. Dussel afirma que a condição para o re-conhecimento do sofrimento é a confiança no outro, que resulta em credibilidade em alguém, nunca em algo. É preciso confiar em sua palavra, acreditar na veracidade de sua dor, como sua revelação que é testemunhada. Este "ato de fé" no outro provoca um tipo de aliança (DUSSEL, 1977, p.140).

Nos relatos do sofrimento, que apresentam como as vítimas compreendem sua ação no cotidiano visando continuar sua vida, aparece-nos como se sujeitificaram ao reconfigurar seu lugar social, criando brechas e espaços novos de sociabilidade. Nos relatos, o testemunho da vítima aparece com o vigor de quem, condenado a desaparecer do cenário de sentidos da realidade, reconstrói pacientemente, em pequenos gestos do dia-a-dia, as ligações humanas que haviam perdido sua coerência e razão-de-ser durante o evento crítico. Estes relatos testemunham uma atitude subversiva, "impensável", não planejada nem prevista, em que na simples existência como insistência, reparam-se as relações e permite-se "reconhecimento para aqueles indivíduos que as normas oficiais têm condenado" (DAS, 2008, p.248). Não é o discurso acadêmico que gera a consciência, mas esta é resultado da experiência da necessidade de viver.

Para Carvalho, as formas em que os indivíduos, que são condenados ao sofrimento social

\footnotetext{
${ }^{16} \mathrm{Em}$ um segundo momento, perceber as instituições que geram a violência e as justificativas que legitimas as instituições que afetam diretamente a vítima. A voz do sofrimento da vítima acusa ao seu modo uma injustiça na sociedade. A interpelação que resulta do sofrimento questiona certas relações sociais concretas em perspectiva de mudança. Para Dussel, esse movimento é a essência da Tese XI de Marx sobre Feuerbach (DUSSEL, 1995, p.155).
} 
pelas instituições oficiais, encontram novas formas de reconhecimento, advém de um tipo de conhecimento efetivo que intervém no imaginário social:

Essa ação "subversiva" não implica, assim, em ruptura, mas na elaboração do que compreendo ser uma nova cena, uma imagem social diferente que permite acomodar aqueles mesmos atores sociais e seus afetos. Uma ação efetiva sobre o imaginário que contém todos esses elementos (CARVALHO, 2008).

A ação efetiva sobre o imaginário social que abre novas possibilidades para a vida humana mostra um modo de tornar-se sujeito através do relato que reconta o sofrimento, buscando formas de continuar a existência. É uma forma de articular a maneira de ser e o conhecimento do vivido. Narrar o sofrimento não é o único modo de re-significar a vida na estratégia do tempo que acontece no cotidiano. O testemunho apresenta formas de elaboração de significados nãonarrativos, no qual o silêncio da vítima não é uma memória reprimida, mas uma estratégia de apropriação da dor. Segundo Veena Das

as transações entre o corpo e a linguagem levam a uma articulação do mundo, em que a estranheza do mundo revelada pela morte, por sua não habitabilidade, pode ser transformada em um mundo em que pode se habitar outra vez, com plena consciência de uma vida que deve viver na perda (ORTEGA, 2008, p.40).

O sofrimento não-narrado pela linguagem da fala pode ser expresso nas linguagens do corpo. O silêncio do sofredor comunica em seu corpo saberes próprios de quem está sofrendo. O corpo silencioso testemunha uma dor profunda. O corpo mudo pode ser rebelde. Rebelde e vivo, reclama seu lugar. Testemunhando sua dor, manifesta sua presença e, assim, questiona a legitimidade da ordem que o vitima. A presença do corpo mudo, vitimado, constitui um tipo de rebeldia ao não aceitar sua necessária exclusão.

A vítima da violência brutal, mesmo silenciada em sua voz, torna-se testemunha em seu corpo. A mulher vitimada na Partição se expressa numa zona de silêncio. Segundo Pereira (2016), o corpo é signo da "gramática violenta de gênero", apropriado na disputa sócio-política. Das propõe que os sujeitos enfrentam a violência não com uma memória paralisada, mas dinâmica, como uma forma de reabitar o cotidiano. O instrumento desta intervenção é o tempo, reconstruindo as relações dos sofredores que buscam as possibilidades para a vida real. A 
reinterpretação da memória, no "trabalho do tempo", permite descobrir as brechas de reinserção na existência do mundo vivido.

Neste sentido, mesmo embrenhado de um conhecimento envenenado, surgem visões significativas através de outros conjuntos de saberes válidos no cotidiano. Veena Das aposta na capacidade que a angústia da dor possui de transcender o mutismo, por exemplo, na dimensão religiosa. Para a pesquisadora, na linguagem religiosa a pessoa que sofre pode viver, a partir de seu passado, de modo diferente, pois "esta maneira de voltar a narrar os acontecimentos mais dolorosos às vezes permite às pessoas abandonar uma posição de imobilismo" (DAS, 2002, p.454).

A apropriação do sofrimento e sua transformação para ação coletiva é uma questão de profunda ambiguidade. Nessa reflexão, Das contrapõe em um esquema categorial a figura grega de Antígona e uma mulher indiana de nosso tempo, Asha. Nos dois casos, teríamos mulheres como testemunhas da dor provocada em situação de sofrimento social. Em Antígona, temos um modelo heroico de resistência às instituições e à lei. A personagem possui plena consciência e reivindica a ilegitimidade da lei social que impõe violência e sofrimento. Dramaticamente em uma encruzilhada entre cumprir a lei das instituições que impõe a dor ou resistir e enfrentar, transgride as normas sociais que considera injusta e violenta, reivindicando outras normativas valorativas.

Em Asha, mulher indiana que sofre as consequências indiretas da Partição, que ao perder o marido nos conflitos, passa a enfrentar a opressão das instituições estatais, religiosas e familiares que gestam formas de submeter e controlar sua existência, encontramos um discurso de resistência diferenciado. A figura de Asha exemplifica um sujeito que possui "conhecimento envenenado", que atua sob o signo das feridas que a afetaram e busca uma possível continuidade no espaço de devastação em sua existência. Se a vida foi afetada brutalmente por fatos impostos pela realidade social, então "o passado encontra o presente não necessariamente como uma memória traumática, mas como um conhecimento envenenado" (DAS, 2008, p.244).

Asha atua no cotidiano, enquanto Antígona sobe ao plano de ruptura dos sentidos gerais da história. São as ações cotidianas que permitem a criação de um discurso de reparação. O testemunho de Asha narra um discurso que não contém apenas palavras, mas se expressa através de performances nas quais os corpos mostram que há algo mais a ser dito. 
Um exemplo forte é quando Asha percebe-se um incômodo para o seu irmão, que nunca foi expresso diretamente, mas comunicado e percebido em "um discurso velado e numa estética de gestos". Segundo Das, a fala continha "palavras não ditas, gestos performáticos, e todo um repertório de noções culturalmente densas que envolviam as expressões" (DAS, 2008, p.228). São duas formas de conhecer, a intelectual e a estética, ambas embrenhadas dentro da cultura local que forma seu contexto. Este entrelaçamento estimula questões para pensar a Filosofia da Educação. Formulam a noção de que os sentidos construídos a partir do mundo vivido muitas vezes apenas são compreendidos através de um conhecer pelo sofrer e somente pela razão geométrica. Como bem apresenta Carvalho, Das argumenta que "Asha irá realmente conhecer através da paixão (sofrimento)" (CARVALHO, 2008, p.15).

Quando, através de seus gestos cotidianos, trabalha na recuperação das relações familiares, age numa linguagem diferente, através de uma forma de conhecer que não é simplesmente intelectual, nem mesmo fundamentada na lógica tradicional ou na coerência de sistemas de significação. É baseada no conhecimento advindo da paixão, enquanto o sofrer que, ao desafiar as possibilidades da vida pela dor, recolocou-se em movimento entre pequenas alternativas nas quais se pode buscar as brechas para significar novamente seus relacionamentos, mesmo diante do envenenamento derramado sobre ela (DAS, 2000).

Asha relata na sua vida um significado de transgressão, em que a lei e a resistência à lei estão juntas, de forma ambígua. São duas realidades que não se opõe completamente, mas que no cotidiano, uma supera a outra na perspectiva de um significado que permita continuar a vida. Transgredir, em diversas estratégias, como maneira de insistir e como processo de sujeiticizar, expressam uma forma de conhecer afetada pela experiência do sofrimento, por vezes absurdo.

\section{Considerações}

No âmbito das relações sociais, Veena Das entende a violência como fruto da ação das instituições sociais, que nega a dignidade e, muitas vezes, as possibilidades da vida humana, modificando as relações pessoais e a maneira de ser de cada um em determinado grupo social. Esta relação está presente de algum modo no pensamento crítico produzido na América Latina, como por exemplo, na Escola do DEI, permitindo um diálogo profícuo. Hinkelammert aponta que 
muitas instituições que anunciam a possibilidade da vida em seu projeto de sociedade, seguem gerando vítimas em nome de sua ação. Quando a instituição que gera o sofrimento considera a violência necessária, expressa uma lógica racional que tem afinidades estruturais com uma razão mítico-teológica sacrificial, que Hinkelammert relaciona com o "endurecimento do coração" denunciado na tradição judaico-cristã (HINKELAMMERT, 1998, p.42). Esse endurecimento do coração é um tipo de conhecimento com postura cínica frente ao sofrimento social. Tem relação interessante com a "falta espiritual" que Das indica no conhecimento cúmplice ou indiferente à dor do outro.

Nosso argumento convida a pensar que seria na experiência da dor, do sofrimento e da compassividade que as ciências humanas são desafiadas a construir um locus de verdade, sem se tornar mais um dos discursos normalizadores dentro de um horizonte de plausibilidade da teodiceia vigente. Da experiência de uma situação limite, surge a produção de um conhecimento. A perspectiva do sofrimento social questiona a razão de ser do conhecimento acadêmico e indaga como o conhecimento da dor do outro pode modificar o lugar institucional do produtor do conhecimento.

Conhecer a dor alheira, ao ser interpelado, necessariamente leva a modificar o nível de reflexão em que se situam as opções fundamentais de cada um, exigindo o reconhecimento da dor do outro ou conduzindo à dúvida desta experiência de sofrimento. Veena Das propõe uma profunda modificação também na compreensão do engajamento do pesquisador social e do intelectual na academia em busca das formas do conhecer. Nosso texto buscou contribuir na compreensão das lógicas em que o conhecer tem algum tipo de compromisso como uma solidariedade na com-paixão.

A perspectiva e contribuição da teoria pós-colonial sugerem que, se o intelectual desejar produzir ciência social com relevância para as vítimas, é convidado a dialogar com outras racionalizações, como também indica Boaventura de Souza Santos em sua categoria da "ecologia de saberes" (SANTOS, 2019). Aqui, incluiria o conhecimento que vem da solidariedade e da compaixão, com metodologia distinta da tradicional racionalidade positivista. Esse tema precisa ser aprofundado. O conhecimento perspectivado ressalta a agência do sujeito da dor que reivindica, ao seu modo, sua dignidade.

O compromisso com as vítimas produz um engajamento prático e teórico que modifica 
as formas de compreensão da realidade, desafiando as reflexões sobre a formação do conhecimento. Este compromisso, no nível dos fundamentos anteriores a qualquer metodologia, modifica as ciências sociais e a Filosofia. No entanto, permanece a acusação de que, se preferir ignorar o sofrimento da vítima, produziremos um conhecimento educacional bastante cínico e cúmplice das formas de ocultação e silenciamento que esmagam o sujeito humano em sua dor.

\section{Referências}

CARVALHO, J. E. C. Violência e sofrimento social: a resistência feminina na obra de Veena Das. Saúde e Sociedade, São Paulo, v.17, n.03, p.9-18, jul.-set 2008.

COELHO, A. S. Capitalismo como religião: uma crítica a seus fundamentos mítico-teológicos. 2014. 281f. Tese (Doutorado em Ciências da Religião) - Programa de Pós-graduação em Ciências da Religião, Universidade Metodista de São Paulo, São Bernardo do Campo, 2014.

COELHO, A. S. Legitimação teológica do sofrimento como pedagogia: uma crítica em Veena Das. Revista Educação [online], PUC-RS, v.40, p.41-52, 2017.

COELHO, A. S. Horizontes de plausibilidade sob a crítica da filosofia: entre luzes, horrores e vítimas. Reflexão e Ação [versão eletrônica], v.26, p.34-51, 2018.

COELHO, A. S., La guerre des dieux et la lutte pour les droits sociaux au Brésil : l'éducation populaire comme pari du christianisme de la libération. In: KAENNEL, L; ANDRADE, L. M. (orgs.) Religions de la libération: espérance, justice sociale et politique. Paris: Van Dieren Éditeur, 2020, p.120-140.

COELHO, A. S.; CORREIA, J. A. C. A. Banalização da injustiça social e a pedagogia do sofrimento: categorias para pensar a educação sob o neoliberalismo. Contrapontos [online], v.19, p.90-103, 2019.

DAS, V. Sufrimientos, teodiceas, prácticas disciplinarias y apropiaciones. Revista Internacional de Ciências Sociales, [Antropologia: temas y perspectivas: II. Explorar nuevos horizontes]. UNESCO, n.154, 2002.

DAS, V. "El acto de presenciar: violencia, conocimiento envenenado y subjetividade". In: ORTEGA, F. A. (ed.), Veena Das: sujetos del dolor, agentes de dignidad. Bogotá: Universidad Nacional de Colombia / Instituto Pensar, 2008, p.217-250.

DAS, V. The 'new normal' in healthcare a myth. Deccan Chronicle, 28 jun.2020. Disponível em: https://www.deccanchronicle.com/opinion/columnists/280620/veena-das-the-new-normal-inhealthcare-a-myth.html. Acesso em: 28 jun. 2020. 
DAS, V.; KLEINMAN, A.; LOCK, M., Social suffering. Berkeley: University of California Press, 1997.

DAS, V.; POOLE, D. El estado y sus márgenes; etnografias comparadas. Cuadernos de Antropología Social, UBA, n.27, p.19-52, 2008.

DUSSEL, E. Para uma ética da libertação latino-americana: eticidade e moralidade, São Paulo/ Piracicaba: Loyola/ UNIMEP, 1977.

DUSSEL, E. Filosofia da libertação: crítica à ideologia da exclusão. S. Paulo: Paulus, 1995.

DUSSEL, E. Ética da libertação: na idade da globalização e da exclusão, Petrópolis: Vozes, 2000.

FREIRE, P. Pedagogia do oprimido. Rio de Janeiro: Paz e Terra, 1979.

HINKELAMMERT, F.J. El grito del sujeto, San José: DEI, 1998.

HINKELAMMERT, F.J. El retorno del sujeto reprimido. Bogotá: Universidad Nacional de Colombia, 2002.

LÖWY, M.; NAÏR, S. Lucien Goldmann: ou a dialética da totalidade. São Paulo: Boitempo, 2008.

ORTEGA, F. A. Rehabitar la cotidianidad. In: ORTEGA, F. A. (ed.), Veena Das: sujetos del dolor, agentes de dignidad. Bogotá: Universidad Nacional de Colombia / Instituto Pensar, 2008, p.1569.

PEREIRA, P. P. G. Violência, gênero e cotidiano: o trabalho de Veena Das. Cadernos Pagu, n.35, São Paulo, p.357-369, jul.-dez. 2010 [2016). Disponível em:

https://periodicos.sbu.unicamp.br/ojs/index.php/cadpagu/article/view/8644975. Acesso em: mar. 2016.

SANTOS, B. S. O fim do império cognitivo: a afirmação das epistemologias do sul. Belo Horizonte: Autêntica, 2019.

WIRTH, L. E. Religião entre o instituído e as vivências cotidianas: chaves de leitura a partir de Michel de Certeau e Veena Das. Caminhos, Goiânia, v.14, n.1, p.275-290, jan./jun. 2016.

Recebido em abril 2020.

Aprovado em setembro 2020. 